\title{
Malignant Neoplasm, Uncertain Whether Primary or Metastatic
}

National Cancer Institute

\section{Source}

National Cancer Institute. Malignant Neoplasm, Uncertain Whether Primary or

Metastatic. NCI Thesaurus. Code C65153.

A malignant neoplasm in which the examined tissue can not be determined with certainty if it represents the primary site of tumor growth or tumor spread from another anatomic site. 